\title{
Fortaleza/CE, cidade sede da alegria: produção do espaço urbano, city marketing e segregação na zona costeira da quinta maior metrópole brasileira
}

\author{
Fortaleza/CE, head city of joy: production of urban space, city marketing and \\ segregation on the coastal zone of the fifth major Brazilian metropolis
}

Tiago da Silva Castro

Mestre em Geografia pela Universidade Federal do Ceará (UFC), Brasil

Membro do Laboratório de Planejamento

Urbano e Regional (LAPUR - UFC)

tiagocgeo@ hotmail.com

Nayrisson de Jesus Prado da Silva Mestre em Geografia pela Universidade Federal do Ceará (UFC), Brasil

Membro do Laboratório de Planejamento

Urbano e Regional (LAPUR - UFC)

ny.prado9@gmail.com

Fátima Aurilane de Aguiar Lima

Bióloga, Mestre em Desenvolvimento e Meio Ambiente pela Universidade Federal do Ceará, fatimaaurilane@gmail.com

Francisco Alexandre Coelho Mestrando em Geografia pela Universidade Federal do Ceará, Bolsista FUNCAP Integrante do Laboratório de Planejamento Urbano e Regional - LAPUR alexandrecoelho75@gmail.com

\begin{abstract}
Resumo
Fortaleza evidencia-se, no cenário das metrópoles brasileiras, pelas dinâmicas referentes ao avanço das práticas marítimas modernas na zona costeira, notadamente a vilegiatura marítima, o turismo e a atividade portuária. Referido processo está pautado na apropriação do litoral pelas classes abastadas, gerando conflitos e esgarçamento do tecido social urbano. Elevada ao status de lócus do segmento turístico de sol e praia, a capital cearense busca a diversificação de seu produto através da inserção do turismo de eventos e negócios, alocando equipamentos e receptando eventos voltados à atração de empresários, praticantes de esportes, amantes de megaeventos esportivos e visitantes em busca de outras segmentações turísticas. Dessa forma, o artigo busca abordar a imagem de Fortaleza publicizada no mercado turístico, evidenciando a atuação dos agentes produtores do espaço urbano e os conflitos existentes no litoral norte da capital. Abordagens sobre o planejamento urbano e a conformação da imagem da cidade são importantes para a compreensão do desenvolvimento do turismo, da gradual inserção na divisão territorial do trabalho e da atração de investimentos públicos e privados. Nota-se que a valorização da zona costeira, o fomento a eventos e a modernização da infraestrutura são estratégias na busca pela consolidação da capital cearense como principal nó da rede urbana de cidades litorâneas do estado, e um dos principais destinos turísticos do país, permeado de segregação, resistências e conflitos.
\end{abstract}

Palavras-chaves: Turismo, Imagem turística, Conflitos socioespaciais, Segregação. 


\begin{abstract}
Fortaleza evident itself, in the scenario of the brazilian metropolises, by the dynamics related to the advance of modern maritime practices in the coastal zone, notably the maritime vilegiature, tourism and port activity. Referred process is based on the appropriation of the coast by the wealthy classes, generating conflicts and tearing of the urban social tissue. High to the status of place of the tourist segment of sun and beach, the capital of Ceara search the diversification of its product through the insertion of tourism of events and businesses, allocating equipment and hosting events aimed to attract entrepreneurs, sportsmen, lovers of sports megaevents and visitors in search of other tourist segments. Thus, the article seeks to approach the image of Fortaleza publicized in the tourist market, evidencing the performance of the producers agents of the urban space and the conflicts on the north litoral of the capital. Approaches about urban planning and the conformation of the city's image are important for the understanding of the development of tourism, of the gradual insertion into the territorial division of labor, and of the attraction of public and private investment. It's noteworthy that the valorization of the coastal zone, the promotion of events and the modernization of infrastructure are strategies in the search for the consolidation of the capital of Ceará as the main node on the urban network of coastal cities of the state, and one of the main tourist destinations in the country, permeated by segregation, resistance and conflicts.
\end{abstract}

Keywords: Tourism, Tourist image, Sociospatial conflicts, Segregation.

\title{
1. INTRODUÇÃO
}

Desde início do século XIX, a cidade de Fortaleza/CE é palco de intensas transformações na tessitura urbana. Com a construção do Porto de Fortaleza, em 1870, Fortaleza é alçada ao posto de principal cidade cearense, exercendo influência e mesmo controle sobre o restante das cidades da região (DANTAS, 2011).

Até o início do século XX, o contato das elites fortalezenses com as elites europeias corroborou para a formação de imaginário social no qual o litoral representa beneficio àqueles que podem usufruir de sua ambiência, ocasionando assim a adoção gradual de práticas marítimas voltadas ao lazer e ao ócio na zona costeira de Fortaleza. Se até início do século XX o litoral representava espaço ocupado e funcionalizado pela atividade pesqueira e portuária, mencionadas mudanças transformam o litoral em espaço a ser utilizado para atividades terapêuticas, caminhadas, banhos de sol e de mar (DANTAS, 2011).

Dantas (2011) ainda infere que as referidas atividades suscitam primeiro esboço de apropriação dacosta de Fortaleza pelas classes abastadas, ocasionando inserção das primeiras casas de veraneio ${ }^{1}$, bem como a progressiva infraestruturação urbana junto à costa, caso das linhas de bonde, energia elétrica e, posteriormente, a construção de casarões e clubes. Citadas obras passam a disputar, com certa vantagem, o domínio do litoral norte de Fortaleza, ocasionando a retirada de residências de pescadores e parte das embarcações ali aportadas.

\footnotetext{
${ }^{1}$ Exemplo são as casas religiosas, presididas por Irmãs de Caridade, que abrigavam os acometidos pelas doenças respiratórias, como a tuberculose.
} 
A partir dos anos de 1940 a ocupação da zona costeira fortalezense se intensifica, quando, na praia de Iracema, se materializam diversas casas de veraneio, bares, restaurantes e pequenas hospedagens. Ainda na década de 1950, há instalação do Porto do Mucuripe, desativando a antiga zona portuária da capital e configurando surgimento imbricado de zona industrial, infraestrutura logística e consequente ocupação do entorno por moradias populares. Denota Silva (1992) que é neste ponto do litoral de Fortaleza que se forma nova zona de meretrício da cidade, pautada pela proximidade da mão de obra do porto.

Já em 1960, a urbanização substancia-se na praia do Meireles, com alocação de habitações das classes abastadas, sendo fomentada pela construção da avenida Beira Mar (1963). Este processo não impossibilita o tradicional uso das praias, apesar de dificultá-lo.

Na ponta do Mucuripe instala-se a sede da colônia de pescadores de Fortaleza até 1990, enquanto a Barra do Ceará, no eixo da avenida Francisco Sá, incorporado pelo lógica industrial proposta pela Superintendência de Desenvolvimento do Nordeste (SUDENE), permanece com importante caráter habitacional, denotado pela alocação dos contingentes de operários na região de dunas (SILVA, 1992).

As avenidas Santos Dumont e Zezé Diogo, instaladas na década de 1970 na porção leste de Fortaleza, possibilitam a chegada das elites à praia do Futuro, exclusividade que não dura muito anos, sendo abalada por linhas de ônibus que transportavam a população menos abastada da capital até este novo espaço litorâneo da cidade.

Mencionadas vias também ocasionam ocupação no litoral leste da capital pela comunidade do Caça e Pesca e especulação imobiliária sobre as dunas defronte à praia do Futuro, possibilitando a criação do bairro Dunas e do mais recente bairro de Lourdes, gerando uma acentuada heterogeneidade socioespacial.

Até a década de 1970, constata-se processo espontâneo de apropriação das zonas de praia pela sociedade local, configurando espaço voltado ao lazer e ao trabalho. A partir dos anos de 1980, há adoção efetiva da maritimidade para a imagem de Fortaleza, com irrefutável influência governamental no planejamento da imagem da Cidade do Sol, buscando desenvolver o turismo como base econômica do litoral do Estado. Destarte, verifica-se importante melhoramento da malha viária e expansão da rede hoteleira no litoral da capital.

A criação da Empresa Cearense de Turismo S.A (EMCETUR), em 1979, identifica-se com visão empreendedora do poder público estadual, sendo o órgão responsável pela divulgação de Fortaleza no mercado turístico nacional e internacional. Soma-se a isto a reestruturação urbana impelida na cidade, caso de calçadões no litoral (1980), a instalação da ponte sobre o rio Ceará (1997), a ampliação do Aeroporto Pinto Martins (1998) e o Projeto Orla (2004). São muitas as ações que buscam dotar a capital de infraestruturas turísticas. 
Neste contexto, Fortaleza/CE se insere como um dos principais destinos turísticos de sol e praia no Brasil, ainda buscando se inserir no mercado global do segmento turístico de eventos e negócios.

Tal busca se evidencia pela construção recente de equipamentos como o Centro de Eventos do Ceará (2013), o aterro da praia da Iracema (2000), o Centro de Formação Olímpica do Ceará (2016), a reestruturação da rede hoteleira, objetivando recepção de eventos e a concretizada eleição de Fortaleza como cidade sede da Copa do Mundo FIFA 2014, o que tem por consequência a transformação do Estádio Plácido Aderaldo Castelo em Arena Multifunção Castelão, a continuidade das obras do Metrô de Fortaleza (METROFOR) ${ }^{2}$ e o início das obras de nova ampliação do Aeroporto de Fortaleza.

Portanto, cabe analisar o planejamento e os rebatimentos no processo de reestruturação da cidade de Fortaleza como parcela do mercado turístico global, evidenciando a atuação dos agentes produtores do espaço urbano na constituição de imaginário da cidade espetáculo e nos conflitos no litoral de norte Fortaleza como espaço de crescente valorização e constantemente refuncionalizado pela produção e pelo consumo (LEFEBVRE, 2005).

\title{
2. PLANEJAMENTO E AÇÕES PARA CONSOLIDAÇÃO DA IMAGEM DA "CIDADE DO SOL"
}

Para a contestação da imagem da capital do sertão eram necessários investimentos em marketing e infraestrutura, proporcionando fluidez ao território e possibilidades de usufruto do turismo de sol e praia como base para o desenvolvimento socioeconômico de Fortaleza. Tais ações foram impelidas pela adoção de políticas públicas, as quais, segundo Souza (2006), podem ser definidas como ações formalizadas por meio das quais o Estado influencia na vida da coletividade, desdobrando-se em documentos e sujeitas a avaliações.

Em meados do século XX há aplicação de tais ações ao território cearense. Na década de 1980 chega ao poder grupo político composto por membros do Centro Industrial do Ceará (CIC). Tais governantes inferem a gestão do território cearense com modelo empresarial pautado nos princípios neoliberais. Cita Coriolano (2006, p. 61):

\begin{abstract}
No momento dos dois primeiros governos empresariais, a política definiu-se pelo ajustamento à moralização, à recuperação das finanças estatais, a mudança do discurso e da imagem do Governo e do Estado, na busca de grandes financiamentos e parcerias. Como desdobramento seguinte implantou-se parte da infraestrutura econômica da modernidade institucional, reforçando o estilo empresarial que se mantém até o momento atual. $\mathrm{Na}$ concepção governamental, foram os anos da construção do chamado novo Ceará e da consolidação das mudanças.
\end{abstract}

\footnotetext{
${ }^{2}$ Projeto existente desde 1990, com obras paradas até a eleição de Fortaleza como cidade sede da Copa.
} 
Partindo deste discurso, se concebe novo modelo de planejamento no Ceará, objetivando crescimento econômico através da atração de investimentos privados, fortalecendo o setor industrial, iniciativas de agricultura irrigada, o setor de comércio e serviços, notadamente o turismo.Desta forma, o planejamento estatal busca produzir espaços favoráveis à reprodução do capital.

Esta forma de planejar, segundo Escobar (2010, p. 147) "inevitably requires the normalization and standardization of reality, which in turn entails injustice and the erasure of difference and diversity". Assim, são criados simulacros que acabam por camuflar a realidade local, mostrando apenas o que é considerado atrativo aos visitantes (DEBORD, 1997).

Verificam-se mudanças significativas no modus operandi da propaganda estatal ao publicizar a imagem de Fortaleza. Se nos anos de 1980 a EMCETUR buscava mostrar imagem fidedigna de Fortaleza, ressaltando locais históricos da cidade, a partir de 1990 há massivo direcionamento às características litorâneas do estado, sendo a capital o principal nó deste novo produto turístico. Dantas (2009) ressalta que esta ação publicitária visa conformar a opinião interna sobre a "vocação turística" do Ceará e da capital, enquanto busca fortalecer a imagem do paraíso litorâneo cearense nas escalas regional, nacional e internacional.

Em relação à formação da imagem da capital, Coriolano (2006, p. 75) afirma:

A imagem criada de Fortaleza tem bastante eficácia política, mesmo sem atender as necessidades de bens e serviços acessíveis à maioria de seus habitantes, mas por indicar aquilo que deveriam ou gostariam de ter: o lazer, a beleza, a cultura e a auto-estima. E, assim, a cidade voltada ao turismo parece forjar uma identidade comum aos citadinos, apesar das marcantes desigualdades socioeconômicas.

A imagética utilizada na busca pela mudança de percepção em relação ao Estado e à capital é demonstrada nas Figuras 1 e 2.

Ainda, seguindo este modelo de divulgação do Ceará, infere Aragão (2006) que passa a ser constante a associação do litoral com o corpo feminino. Este fato denota comportamento dos media associados ao turismo não só neste estado, mas também em estados como o Rio de Janeiro e Bahia ${ }^{3}$.

\footnotetext{
${ }^{3}$ Desde 2005 o Governo Federal iniciou campanha buscando coibir os fluxos atraídos pelo turismo sexual e os consequentes casos de exploração sexual de crianças e adolescentes. Tais medidas não conseguiram conter as estatísticas, que tiveram novo crescimento no período que antecedeu a Copa do Mundo de 2014 no Brasil.
} 


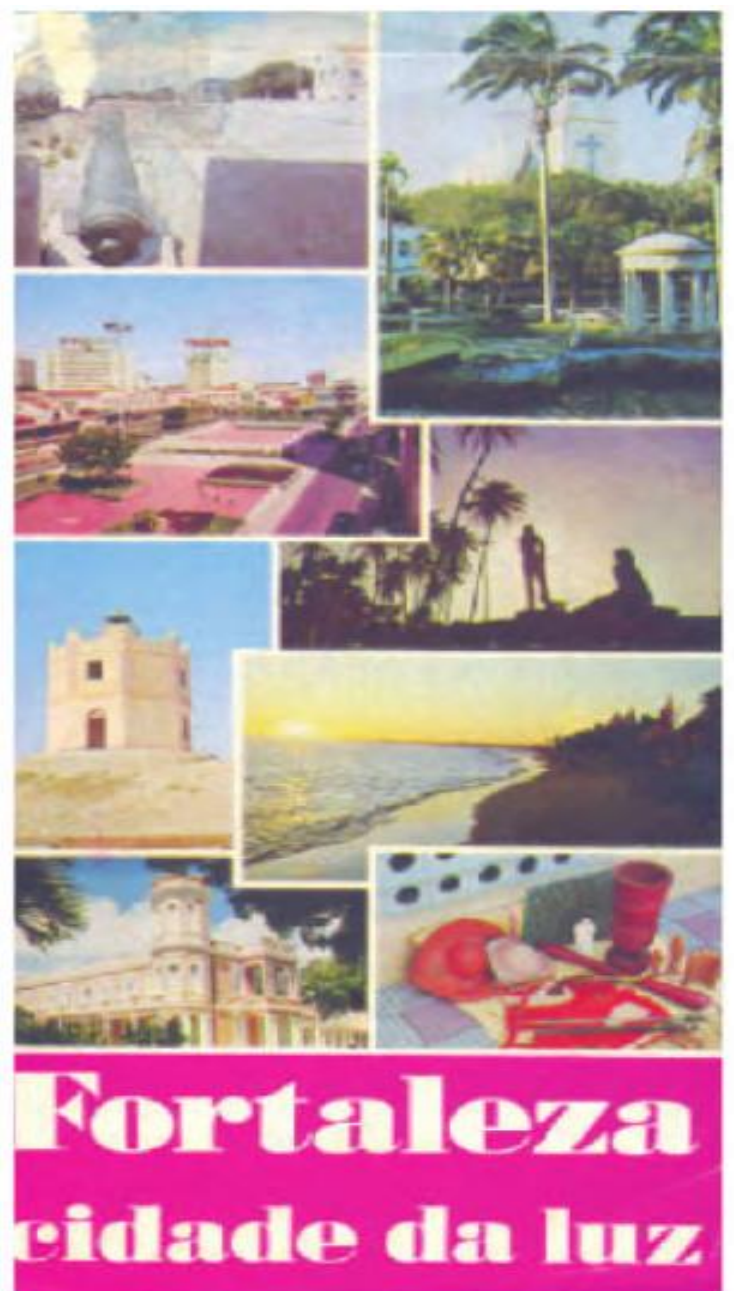

Figura 1 - Folder elaborado pela EMCETUR em meados da década de 1970, ressaltando monumento e prédios históricos como o Forte de Nossa.

Sra. da Assunção, o Farol do Mucuripe e o Parque das Crianças.

Fonte: ARAGÃO, 2006.

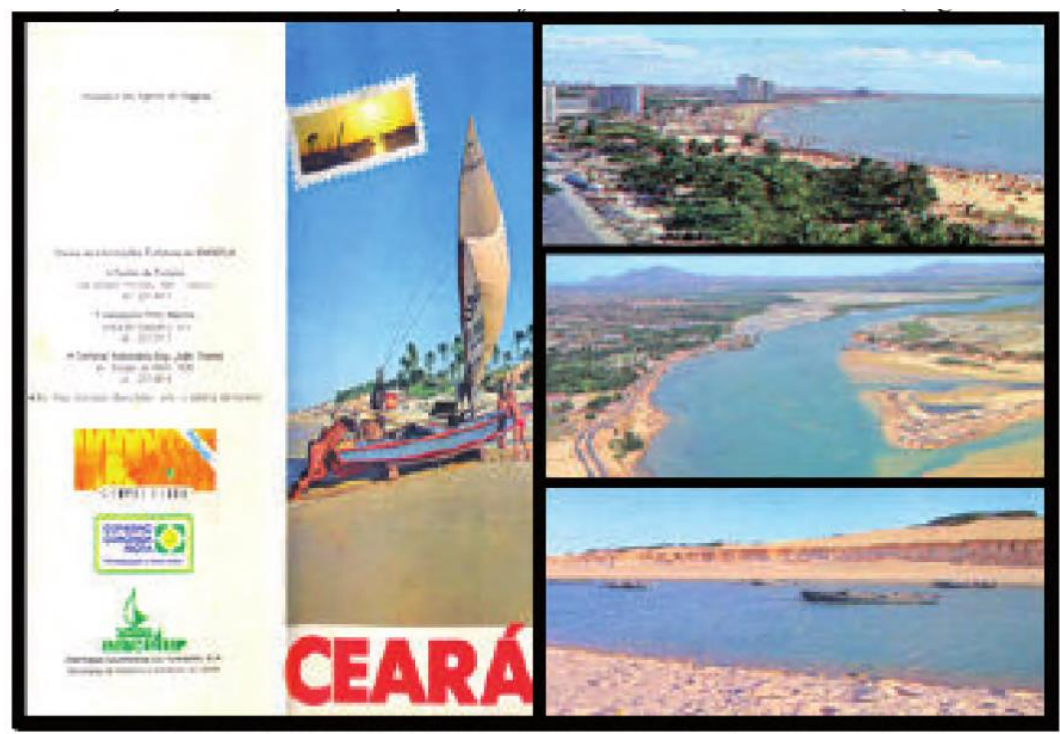

Figura 2 - Folder elaborado pelo Governo do Estado do Ceará, na década de 1980, ressaltando os ambientes litorâneos e o elemento humano característico destas paisagens.

Fonte: ARAGÃO, 2006. 
No início do século XXI há maior busca por mostrar as praias de todo o estado, com pouquíssimos atrativos não-litorâneos ou artificiais representados na imagem cearense, casos dos símbolos do turismo religioso ${ }^{4}$, dos ambientes serranos e de patrimônios como o Teatro José de Alencar e a Catedral Metropolitana de Fortaleza.

Também através dos governos empresariais, há adoção de estratégias para reestruturação do espaço cearense, configurando rede urbana dotada de nó concentrador de fluxos turísticos e distribuidor destes visitantes para o restante do território estadual, mais explicitamente pelos municípios litorâneos.

Assim, constituiu-se imagem que hoje é divulgada nas diversas escalas, ganhando propriedades abstratas representadas pelo extenso litoral, atraindo fluxos de pessoas, de informações, de recursos financeiros e de mercadorias, inserindo-se no contexto global de intensa circulação para além do território local ou mesmo estadual (DIAS, 1995).

É crescente a busca pela valorização e valoração do litoral fortalezense através realização de eventos. Nos últimos três anos, dois eventos esportivos impulsionaram a visitação da capital cearense, casos da Copa do Mundo de 2014 e do IronMan. Durante a Copa foram registrados gastos de cerca de US\$ 1,5 bilhão pelos visitantes internacionais, dados que comprovam a importância da realização desses eventos para a dinamização da economia local. (FORTALEZA, 2015).

Já o IronMan, evento de triátlon que atrai não só os competidores mas também equipes e familiares, movimentou mais de R\$ 10 milhões na economia municipal em 2014 e 2015. Já em 2016 tem leve queda prevista, com expectativa de implementação de R 7 milhões nos dias do evento. Além desses eventos de grande porte, que atraem grande contingente de turistas, podem ser salientados eventos que ocorrem na zona costeira (ou em áreas contiguas a esta) e refletem a valorização desta, como o desfile de 7 de Setembro, Carnaval, Parada do Orgulho LGBTT, Reveillon e Fortal.

O desfile cívico militar de7 de Setembro, anteriormente realizado na Av. Desembargador Moreira, no bairro Aldeota, desde 2002 ocorre na Av. Beira-Mar, no bairro Meireles, reunindo milhares de expectadores. Desfilam Aeronáutica, Marinha, Exército, Bombeiros e Polícia Militar do Ceará, além de instituições civis, entre estudantes de escolas públicas e particulares, representantes de projetos sociais e agremiações (O ESTADO, 2014).

O Carnaval movimenta a economia de todo país, destacando o setor turístico, sendo imprescindível ao alcance de metas financeiras por atrair considerável número de turistas nacionais

\footnotetext{
${ }^{4}$ É comum a utilização das imagens das estátuas de Padre Cícero, em Juazeiro do Norte/CE, e de São Francisco de Assis, em Canindé/CE, bem como da basílica de São Francisco de Assis, nesta mesma cidade.
} 
e internacionais, além de ampliar o comércio, sendo a principal festa nacional. Reiterando os impactos do Carnaval 2014 sobre a economia local, Braga descreve:

A taxa média de ocupação hoteleira no Ceará foi de 92\%. Em Fortaleza, houve pico de $100 \%$ de ocupação durante o período festivo em alguns hotéis. Cerca de 99 mil turistas visitaram o Ceará via Fortaleza no feriado de Carnaval, com taxa de ocupação da rede hoteleira estimada em 92,1\%, de acordo com o Departamento de Estudos e Pesquisas da Secretaria de Turismo do Ceará. O número foi 7,2\% maior que no ano passado. O impacto estimado na economia foi de $\mathrm{R} \$ 123,3$ milhões de receita direta, o que deve resultar em $\mathrm{R} \$$ 215,9 milhões de renda gerada em toda cadeia produtiva do turismo (BRAGA, 2015, p. 01).

A prefeitura também promove editais de apoio ao Pré-Carnaval, para seleção de blocos de rua que irão animar Fortaleza. Os blocos se apresentam no Mercado dos Pinhões, ou seguem em cortejo, concentrando-se no Poço das Dragas, seguindo pela rua dos Tabajaras até o palco do Aterrinho. Outros blocos saem pela rua João Cordeiro, seguindo para o mesmo palco (FORTALEZA, 2015). A figura 3 denota o pré-carnaval de Fortaleza em 2014.

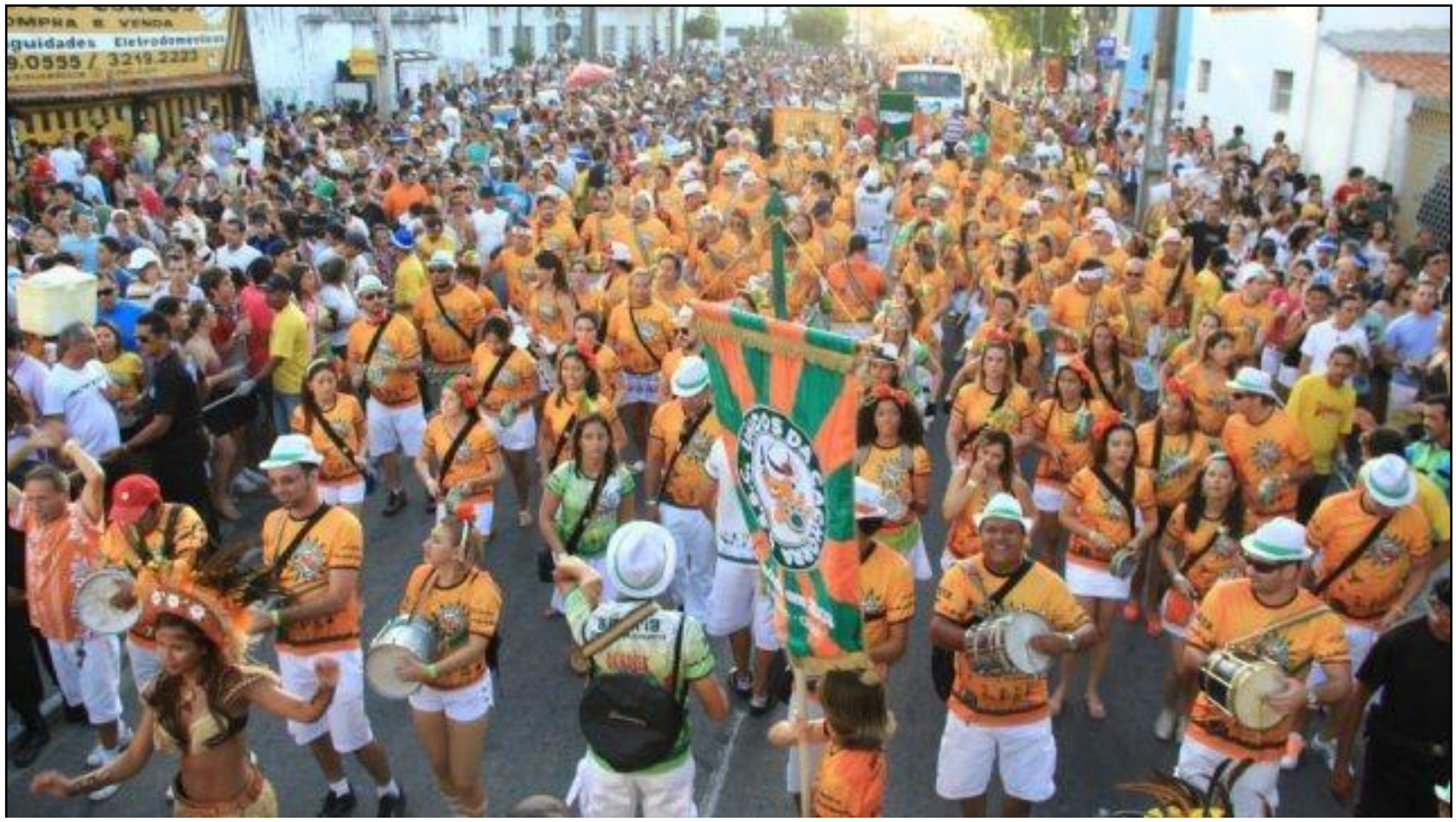

Figura 3 - Pré-carnaval de Fortaleza, composto por blocos como o Unidos da Cachorra.

Fonte: CNEWS, 2014.

Segmento que tem se evidenciado é o turismo LGBTT, direcionado à população de gays, lésbicas, bissexuais, travestis e transexuais. O evento que promove este segmento de turismo é a Parada do Orgulho LGBTT, que ocorre na Avenida Beira-Mar. A capital cearense tem se tornado atrativa ao público LGBTT, fato ratificado por Barros (2015, p.01): 
A capital Fortaleza é o epicentro da badalação gay. Com sol praticamente o ano todo, impossível não curtir a orla da cidade, com praias deslumbrantes e estabelecimentos friendly. As praias de Meireles e a de Iracema são as mais movimentadas e com boa infraestrutura turística. Mais afastada do Centro, a praia do Futuro também é uma opção com barracas frequentadas pelo público gay como a Kabumba e a Croco Beach.

O Reveillon de Fortaleza atrai, anualmente, grande contingente de turistas, sendo essencialmente relevante para a economia local, gerando emprego e renda. O Secretário de Turismo de Fortaleza, em 2012, reitera que o Reveillon que ocorre no aterro da Praia de Iracema, contempla todas as faixas sociais de forma democrática, caracterizando-se como evento de grande porte com qualidade cultural e recreativa, ampliando a oferta turística do estado (O POVO, 2012). Este evento destaca-se pela atual profissionalização e reunião de artistas nacionais e locais. Em 2015, constatouse presença de um milhão de pessoas, configurando-se como o segundo maior Réveillon do país (FORTALEZA, 2015).

O Fortal constitui-se de carnaval fora de época nacionalmente conhecido, reunindo artistas nacionais sobre trios elétricos. Até 2005 era realizado na Av. Beira Mar, sendo realocado na Cidade Fortal, localizada no bairro Manoel Dias Branco, devido a poluição sonora promovida pelo evento. Esta transferência do evento se justifica na tentativa de dinamização do litoral leste de Fortaleza, sendo construída estrutura de recepção de foliões, circuito para trios elétricos e áreas comuns para realização de festas (O POVO, 2006).

Pode-se destacar, por conseguinte, a infraestrutura em alguns pontos litorâneos voltados à recepção de eventos: o Centro Dragão do Mar de Arte e Cultura, a Ponte dos Ingleses (popularmente conhecida como Ponte Metálica), o aterro da Praia de Iracema, o Calçadão da BeiraMar (onde são encontrados hotéis, bares, restaurantes, feirinha de artesanato, shows de humor, praças como Jardim Japonês e a Praça dos Estressados, que possui equipamentos para realização de exercícios físicos) e as barracas da Praia do Futuro.

A Prefeitura de Fortaleza, até novembro de 2014, investiu R \$ 89,9 milhões no turismo, por meio da Secretaria de Turismo. Merecem destaques as ações de promoções do turismo na capital, obras de requalificação e novos projetos em desenvolvimento.

Assim, é correto afirmar que o turismo litorâneo e o turismo de eventos e negócios se mesclam, bem como as tipologias de hospedagem atendem a ambos. E através do planejamento o poder público tenta cultivar nos turistas a noção de que a cidade não é somente sede da Copa, mas sim lugar turístico de belas praias, conforto e serviços de qualidade, pronto para recebê-los. Ainda, cabe ressaltar os conflitos gerados pelo processo de valorização da zona costeira de Fortaleza, as dinâmicas geradas e os processos em curso. 


\section{AGENTES PRODUTORES DO ESPAÇO URBANO E DINÂMICAS CONFLITUOSAS NO ESPAÇO LITORÂNEO FORTALEZENSE}

As transformações no espaço não podem ser atribuídas somente a uma lógica de mercado, nem mesmo a um Estado que idealiza toda a organização, muito menos ao capital abstrato que emerge das relações sociais (CORRÊA, 2004). Estas transformações se realizam a partir dos vários agentes sociais, sendo estes contraditórios, complexos, sociais concretos, históricos e fazendo uso de estratégias para práticas espaciais geradoras de conflitos em todos os recortes da cidade.

À veloz produção do espaço, Harvey (1993) atribui o conceito de compressão do espaçotempo. Os espaços são rapidamente modificados em função do capital, da lógica especulativa, enquanto os conflitos sociais e os demais processos se complexificam, onde os agentes produtores agregam diversas funções.

As metrópoles brasileiras revelam na paisagem esta problemática mediante a segregação socioespacial. No processo de urbanização, as áreas nobres foram ocupadas pela classe abastada, em contrapartida, as áreas periféricas, sem infraestruturas e serviços adequados, abrigaram a população desprovida de bens, sem qualificação profissional, recém-chegada do interior dos estados, que buscam melhores condições de vida como, afirma Giddens (2005):

Com inchamento das cidades, muitas pessoas ficaram horrorizadas ao perceberem que as desigualdades e a pobreza urbana se intensificaram na mesma proporção. A extensa pobreza urbana e as enormes diferenças entre os bairros da cidade estiveram entre os principais fatores que motivaram as primeiras análises sociológicas da vida urbana das condições urbanas modernas e as teorias a esse respeito [...] (GIDDENS 2005 p. 457).

A imagem turística de Fortaleza/CE passou a integrar as ações dos agentes produtores do espaço urbano. Tais ações transformam a zona costeira em espaço de consumo e, sobretudo, de resistência (HARVEY, 2005). O processo de segregação que se realiza na zona costeira fortalezense toma forma nas lutas populares, através de permanência nos locais ambicionados pelos especuladores. Assim, são diversos os conflitos no litoral, potencializados na recente busca pela transformação da Cidade do Sol na Cidade Sede da Alegria ${ }^{5}$.

Cabe ressaltar a importância do planejamento turístico na produção do litoral de Fortaleza. Remetido processo, iniciado na década de 1990 com o PRODETUR ${ }^{6}$, tem continuidade em 2007 com os simultâneos PRODETUR Nacional e a segunda fase do Programa de Aceleração do

\footnotetext{
${ }^{5}$ Slogan utilizado por Fortaleza durante a recepção de jogos da Copa do Mundo FIFA 2014, ressaltando características como a receptividade e o humor dos cearenses e refutando os diversos problemas da dinâmica da metrópole.

${ }^{6}$ Com as duas primeiras fases iniciadas, respectivamente, nos anos de 1995 e 2004 (BNB, 2005; 2010).
} 
Crescimento (PAC II), visando dotar a zona costeira de infraestruturas de lazer e recepção de turistas, voltadas à configuração da cidade espetáculo.

Para transformar Fortaleza em sede de eventos como a Copa do Mundo de 2014, foi planejada a logística de disposição de aparelhos urbanos que contribuem para maior fluidez, conforto e consumo. Ou seja, infraestrutura de transportes, aeroportos, hotéis, shoppings, entre outros que remetem à cidade minimamente pensada para atender às necessidades do evento, ressaltando política desenvolvimentista urbana, que traz para as cidades ares de modernidade e, consequentemente, maior competitividade na atração de investimentos para a metrópole.

Estas ações não se realizam de forma desconectada da tessitura urbana, produzindo conflitos e mudanças nas concepções sobre o planejamento na metrópole. Verifica-se processos contínuos de (re)apropriação do espaço urbano baseados em menores ou maiores possibilidades de renda dos promotores imobiliários, através de ações de reestruturação pautadas pelas esferas públicas, pelo morar e consumir das classes abastadas, e pelo habitar e lazer das classes mais pobres.

As inúmeras funcionalidades da zona costeira de Fortaleza/CE são notáveis também no que tange aos desígnios do planejamento urbano local, reconfigurando este espaço como lócus de especulação imobiliária, através da alocação de projetos imobiliários, turísticos e de lazer recorrentes.

Recebendo transformações pontuais nas duas primeiras fases do PRODETUR-CE, Fortaleza tem o Aeroporto Pinto Martins (1998) como principal investimento voltado à cadeia produtiva do turismo. No PRODETUR-CE II, o litoral é preparado como cartão postal da cidade, recebendo intervenções em alguns monumentos históricos ${ }^{7}$, na requalificação urbanística das praias de Iracema e do Futuro. É no litoral norte da cidade que se dão os principais conflitos territoriais relacionados ao turismo.

As ações de melhoramento urbano ocorrem nos mesmos moldes dos calçadões implantados na década de 1980, visando possibilitar o passeio pela orla fortalezense. Cabe frisar que no entorno das duas praias há intensa ocupação por comunidades carentes, estando a comunidade do Poço das Dragas à oeste da praia de Iracema, e as comunidades do Titanzinho, Vicente Pinzon e Alto da Paz à oeste da praia do Futuro, não permitindo a completa interligação turística do litoral norte de Fortaleza.

A turistificação das orlas está fortemente voltada ao encantamento do público visitante, daqueles que podem consumir no/o espaço, portanto eram necessárias outras formas de segregar os visitantes dos indesejáveis moradores locais. O mapa 1 demonstra o recorte espacial do litoral norte de Fortaleza.

\footnotetext{
${ }^{7}$ Teatro José de Alencar, Casa de José de Alencar, Palácio da Abolição, Fortaleza de N. S. da Assunção, Farol do Mucuripe, Passeio Público, dentre outros.
} 


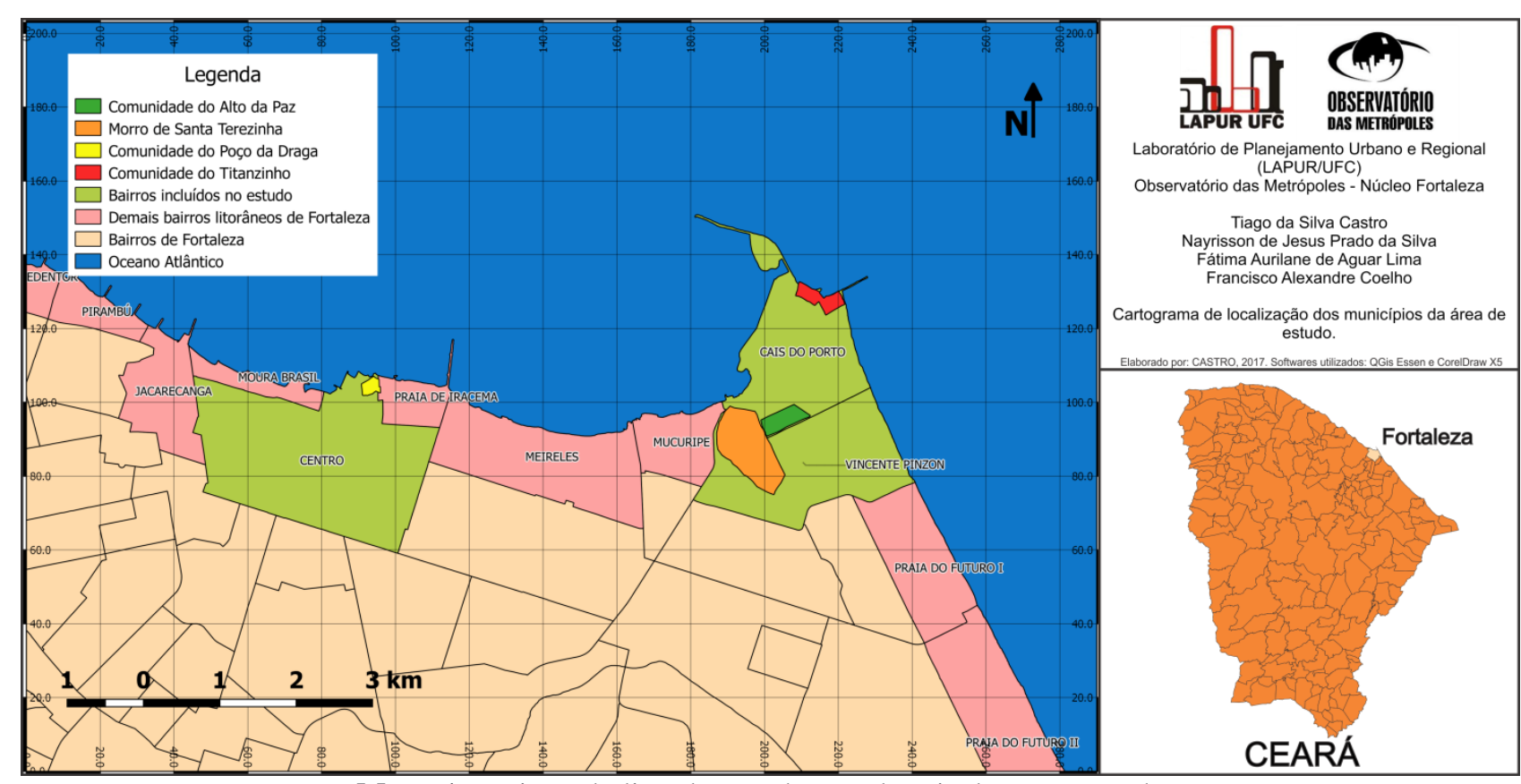

Mapa 1 - Bairros do litoral norte de Fortaleza inclusos no estudo. Elaboração: CASTRO; SILVA (2017)

Desta feita, estes pontos da cidade passam por processo de alocação de equipamentos turísticos, pretendendo diversificar os atrativos na capital, polarizar empreendimentos para o entorno e, consequentemente, agregar valor ao solo ocupado pelas comunidades. Verifica-se, nos anos seguintes, a alocação do projeto do Aquário do Ceará junto à comunidade do Poço das Dragas, e do Terminal de Passageiros do Porto do Mucuripe junto às comunidades localizadas na ponta do Mucuripe.

O anúncio do Aquário do Ceará foi realizado em 2009 sob pretexto de "colocar Fortaleza como cidade referencial para o mundo" (FOLHA DE SÃO PAULO, 2015). Com este mote o Governo do Estado autoriza início das obras em 2012, localizadas em faixa costeira ao lado do antigo porto de Fortaleza, ignorando a inversão de prioridades citada por parte da população local.

Orçado em R\$ 250 milhões, pretende ser o terceiro maior aquário do mundo, gerando, segundo expectativas do Governo do Estado, cerca de 150 empregos diretos, 1.600 indiretos e 18 mil na cadeia produtiva do turismo (UOL, 2013). Imagem favorável criada, não parecia existir problemas ou impactos causados pela obra, até o Ministério Público (MP) embargá-las duas vezes por incoerências constatadas no processo licitatório.

A comunidade do Poço das Dragas nasce junto ao Porto de Fortaleza, recebendo os primeiros habitantes no início dos anos 1900, em busca de ocupações relacionadas à atividade portuária. Com a inauguração do Porto do Mucuripe, os membros da comunidade vêem as condições de vida declinarem severamente. Atualmente existem cerca de 500 famílias residentes, que sofrem com a falta de serviços de educação, saúde ou saneamento básico (O POVO, 2013). A figura 4 demonstra as atuais condições da comunidade. 


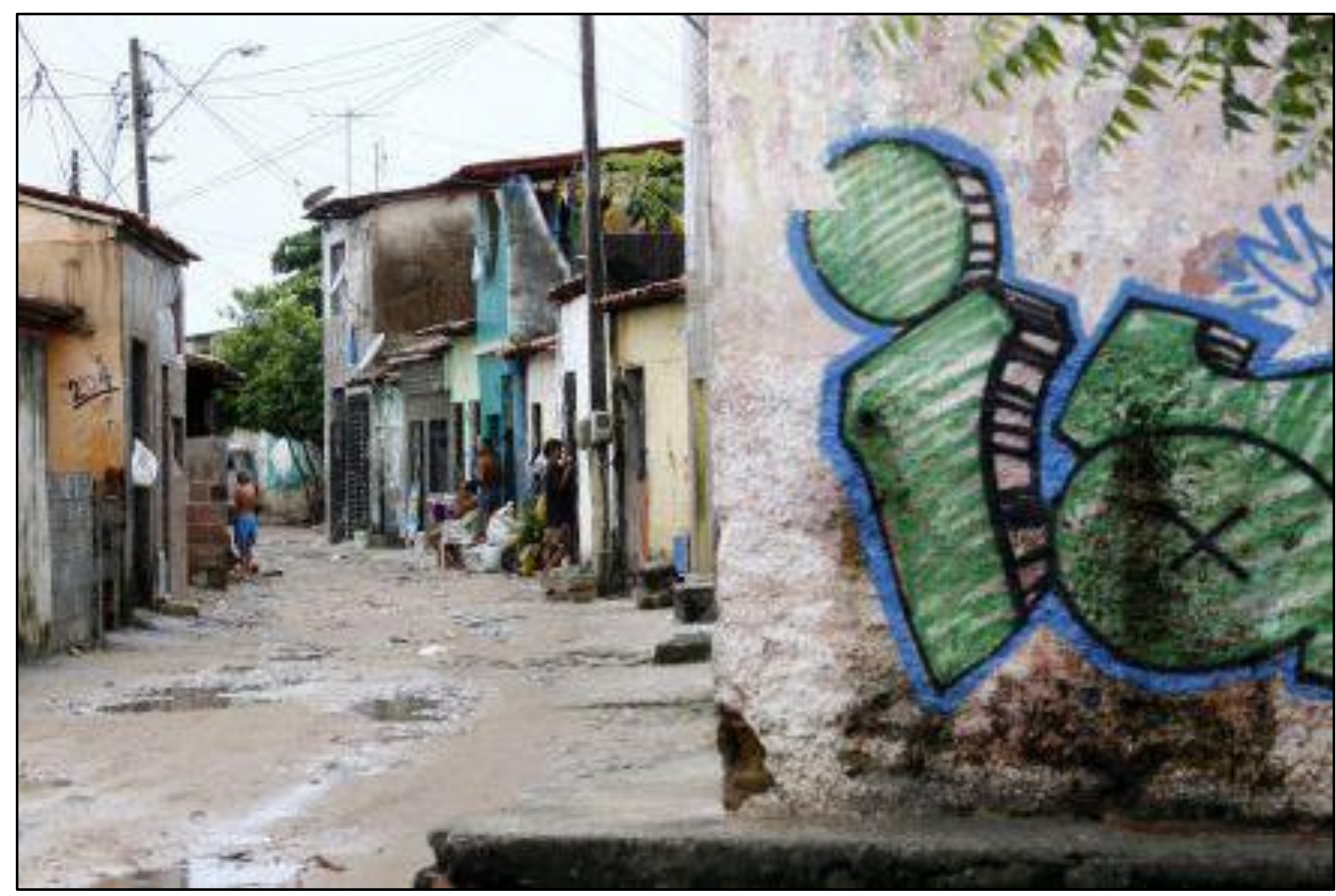

Figura 4 - Ruas sem pavimentação ou saneamento.

Fonte: Comunidade Poço das Dragas, 2014

Com o início das obras do Aquário, cresce o temor das remoções, já iniciadas em outros pontos da cidade ${ }^{8}$. Desta forma, foram negadas quaisquer possibilidades de remoção, o que ocasionou série de desmandos por parte do poder público contra as estruturas físicas e sociais da comunidade. Há, inicialmente, demolição do Centro Comunitário, sem qualquer prévio aviso ou identificação dos responsáveis (O ESTADO, 2010).

Também são destacados os impactos da obra do Aquário nas edificações do entorno, que já apresentam rachaduras e infiltrações. As incongruências presentes no Estudo e Relatório de Impacto Ambiental (EIA/RIMA) também são diversas ${ }^{9}$, denotando a busca incondicional do poder público pela implantação do equipamento (COPA PÚBLICA, 2013).

Na tentativa de amenizar os temores da comunidade do Poço das Dragas, em 2013 foram iniciadas discussões sobre o Projeto Integrado de Regularização Fundiária e Urbanização da Comunidade Poço da Draga, visando requalificar o espaço através de criação da APP do riacho Pajeú, melhorias na infraestrutura viária e habitacional, no saneamento e criação de espaços de lazer, todas as ações a serem inclusas no PAC II, orçadas em R\$ 20 milhões (PREFEITURA DE FORTALEZA, 2011).

Passados dois anos, citado projeto não foi realizado, salientando a inversão de prioridades do poder público. Cita Lefebvre (2008), em relação à economia política do espaço, que as contradições

\footnotetext{
${ }^{8}$ Devido a obras da matriz de responsabilidades sobre mobilidade da Copa do Mundo de 2014, caso das comunidades próximas ao eixo do Veículo Leve sobre Trilhos (VLT), próximas ao estádio Castelão e às vias do entorno desta praça esportiva.

${ }^{9}$ No que tange à demolição do antigo prédio do DNOCS, ao estudo de evolução do impacto das marés na estrutura, ao processo de descarte das águas e animais mortos e à falta de estudo arqueológico da área.
} 
socioespaciais são provenientes da não resolução dos problemas da cidade, sendo estes apenas deslocados para longe da ação do Estado. É por meio das ações da Organização NãoGovernamental (ONG) Velaumar que a comunidade busca a conscientização e organização dos moradores e da sociedade frente aos problemas vividos.

Caso semelhante é verificado na comunidade do Morro Santa Terezinha, localizado entre os bairros Mucuripe, Vicente Pinzon e Cais do Porto, que se constituiu sobre depósitos de dunas em meados da década de 1940, motivada pela instalação do Porto do Mucuripe e de unidades industriais nos referidos bairros (SILVA, 1992). Desde então, sobretudo após os anos de 1970, tem sido alvo de projetos de urbanização da cidade, com ênfase na requalificação. A figura 5 mostra as habitações do Morro Santa Terezinha.

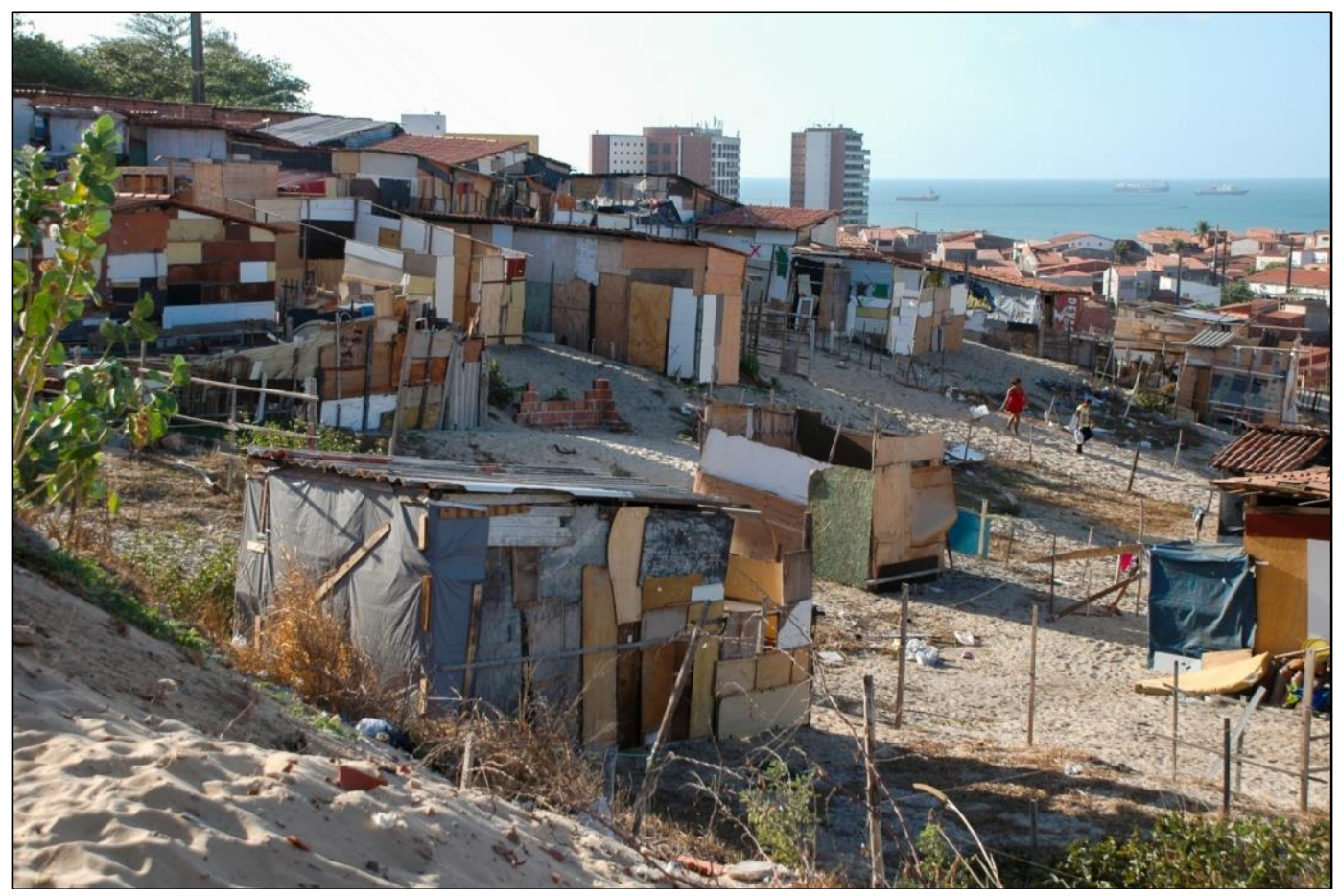

Figura 5 - Habitações no Morro Santa Terezinha.

Fonte: O Estado, 2013.

Com obra orçada em R 10 milhões pelo PRODETUR Nacional, previa implantação de bondinho, anfiteatro, mirante, praças e espaços para a prática de esportes, onde o principal objetivo é ligar o Morro com a Av. Beira-Mar, através de calçadão. (O POVO, 2011). Tal projeto, ainda não foi realizado pelos grupos gestores e o que pode ser visto nesta comunidade é o extremo abandono por parte do poder público.

A ocupação inicial da comunidade é originada por pescadores e trabalhadores do porto recém-inaugurado. Com a chegada dos migrantes das secas, teve forte crescimento populacional na década de 1980, sem o devido acompanhamento dos gestores municipais. A ausência de políticas 
públicas voltadas à melhoria das condições habitacionais classificou a comunidade como de risco ambiental.

Cabe lembrar que a referida cidade tem excluído as comunidades pobres de qualquer ideia de planejamento, visando, no projeto de urbanização de Fortaleza, o crescimento econômico baseado no turismo. As cerca de 1.100 famílias tem, na Associação dos Moradores do Morro de Santa Terezinha, forma de organização para reivindicações e discussões sobre as ações a serem implantadas na comunidade, caso do projeto de urbanização do Morro de Santa Terezinha.

Realidade similar é vivenciada pela comunidade do Titanzinho, que localiza-se no bairro Cais do Porto, próxima ao Porto e ao Farol do Mucuripe, sendo recorrentemente ameaçada pelos interesses estatais (ALDIGUERI et al., 2015), além de enfrentar graves problemas sociais como a criminalidade e a pobreza.

A comunidade também surgiu com a construção do novo porto, que causou vários impactos socioambientais na orla próxima. A comunidade é basicamente formada por famílias de pescadores aposentados, os quais não conseguiram competir com a pesca industrial, formando assim comunidade com diversas carências. $\mathrm{O}$ desenvolvimento do turismo na capital culminou na recente valorização da área, propiciando crescimento intenso na faixa litorânea que liga a praia do Mucuripe à praia do Futuro (CUNHA; PEREIRA, 2014).

Devido à grande valorização do local, a comunidade sofre com as pressões para construção de novos equipamentos turísticos e imobiliários. Caso da construção do Terminal de Passageiros do Porto do Mucuripe, projeto pensado para a Copa de 2014. Este utilizou recursos provenientes da Secretaria de Portos (SEP), que faz parte do PAC II (GOMES JÚNIOR, 2011).

A implantação do Terminal Marítimo de Passageiros no Porto do Mucuripe causou intensas transformações espaciais, já que os novos consumidores do espaço começam a visualizar novas zonas de crescimento imobiliário e instalação de serviços, tornando a ocupação do Titanzinho e o ecossistema estabelecido na Praia Mansa cada vez mais ameaçados pelos interesses dos especuladores (CUNHA; PEREIRA, 2014). A figura 6 ressalta a disparidade entre o Titanzinho e o Terminal Marítimo do Mucuripe.

Neste âmbito, é necessário o fortalecimento de instrumentos como a Zona Especial de Interesse Social (ZEIS), que visam proteger o direito à moradia para pessoas de baixa renda ou que vivem em situações de irregularidade fundiária dentro das cidades, de forma a inserir estas ocupações na cidade formal (PINHOS; FREITAS, 2012).

Outra questão que gerou resistências foi o plano de construção de um estaleiro na região, no ano de 2010. Equipamento pautado pela Transpetro ${ }^{10}$ estava orçado em R\$ 220 milhões. A

\footnotetext{
${ }^{10}$ Divisão de transporte de derivados de petróleo pertencente à Petrobrás.
} 
comunidade do Titanzinho mostra-se bastante articulada e coesa na resolução dos problemas provenientes das pressões externas à comunidade, tendo como principal característica a territorialidade criada pelos surfistas locais, que tem no litoral importante recurso na formação em esportes aquáticos. Após muitos enfrentamentos, conseguiu-se o embargo da obra. Um residente, André Silva, surfista profissional relata: "Foi bom saber que depois de muita luta a comunidade venceu e conseguiu embargar a obra” (PIMENTA, 2010).

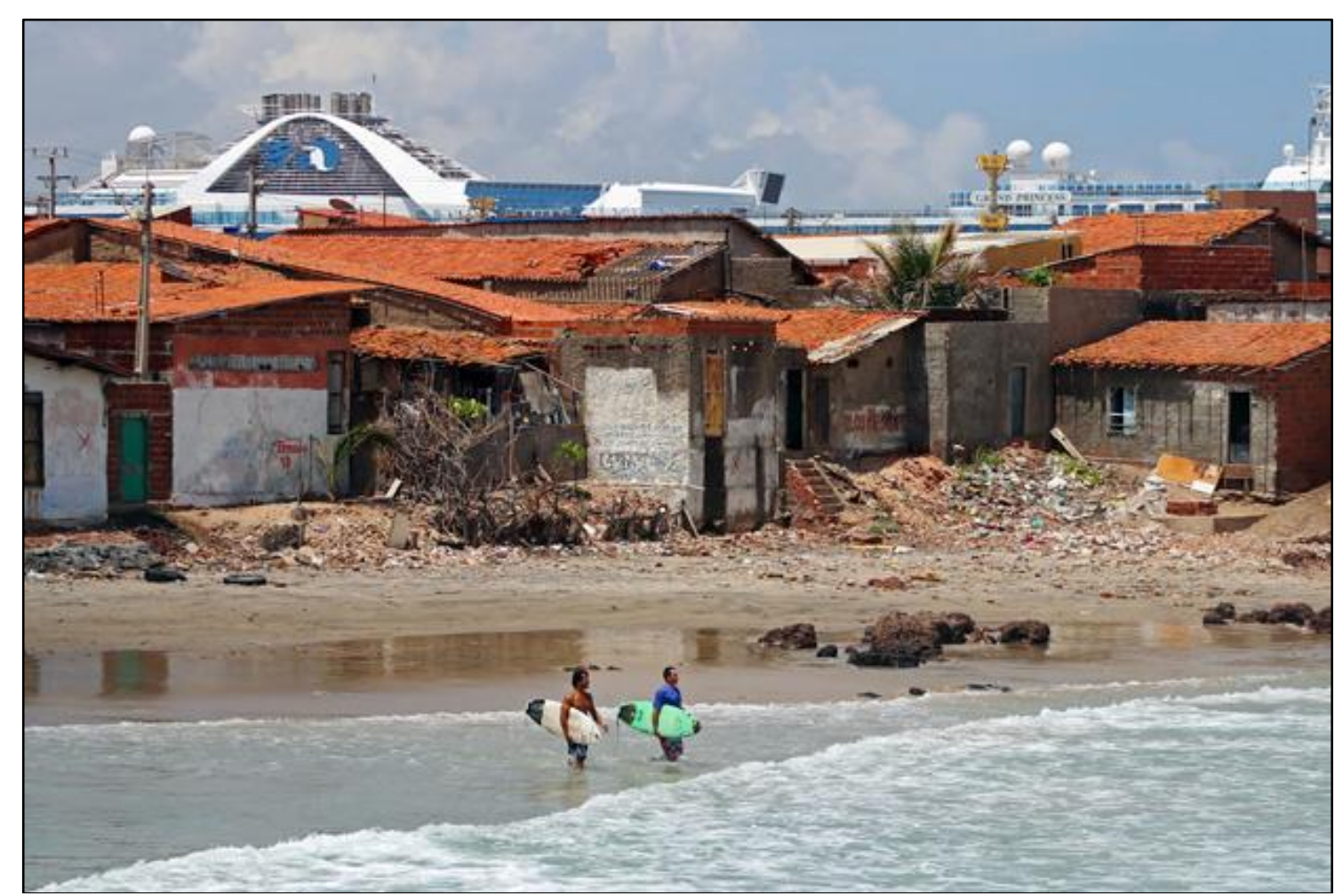

Figura 6 - Carências do Titanzinho frente à suntuosidade do Terminal de Passageiros do Mucuripe.

Fonte: Surf Bahia, S/D.

Próxima à comunidade do Titanzinho, em 2012, há ocupação denominada de Alto da Paz, no bairro Vicente Pinzon. O terreno, que estava desocupado há cerca de 40 anos, seria destinado para construção de cerca de 1.500 apartamentos do programa Minha Casa Minha Vida (MCMV) (O POVO, 2015). Tal projeto visava integração com o projeto Aldeia da Praia, ligando a praia do Futuro à praia do Mucuripe.

O projeto Aldeia da Praia foi orçado emR\$ 104 milhões, recursos do PAC II com participação da Prefeitura de Fortaleza e com execução realizada pela Secretaria de Infraestrutura e Turismo, objetivando integrar a Avenida Beira-Mar com a Praia do Futuro, projetando obras de requalificação urbana, ambiental e social das comunidades do Serviluz e Titanzinho. Com a reurbanização a via principal do Serviluz, a Rua Pontamar, denominar-se-ia de Avenida Paisagística. 
A segunda etapa prevê a melhoria das estruturas nas unidades habitacionais das comunidades e uma praça no entorno do farol do Mucuripe e do conjunto habitacional. Este conjunto habitacional será o Residencial Alto da Paz, destinado ao reassentamento das famílias beneficiadas pelo projeto de urbanização Aldeia da Praia, na praia do Titanzinho, Serviluz e Vicente Pinzón.

Uma série de fatos conturbou a viabilidade do projeto. Inicialmente, no terreno onde será feito o residencial para os reassentados, residiam 328 famílias, segundo a Prefeitura, e 537, segundo a associação de moradores do Alto da Paz. A desapropriação da comunidade do Alto da Paz ficou acertada junto à Fundação de Desenvolvimento Habitacional de Fortaleza (HABITAFOR), com a saída pacífica do terreno em troca da unidade habitacional construída, R\$ 100 de ajuda de custo e cesta básica mensais às famílias durante a construção, a ser fornecido pela construtora responsável (O POVO, 2015).

Porém uma ordem judicial foi expedida para retirada da comunidade, sendo esta desconhecida pelos moradores. Depois de confronto policial, os moradores foram retirados do local, deslocando-se para casas de familiares. Segundo moradora desapropriada, em depoimento ao Jornal O Povo (2014), apenas alguns moradores assinaram o acordo, pois sabiam que teriam de sair, mas não houve aviso prévio de que seria naquele momento e nem com uso de força policial. As ajudas de custo de R\$ 100 só foram pagas por dois meses e a obra não teve início. Em 2015, 80 moradores ocuparam o terreno novamente, exigindo celeridade na obra para construção do residencial. A figura 7 denota a situação do local após desapropriação.

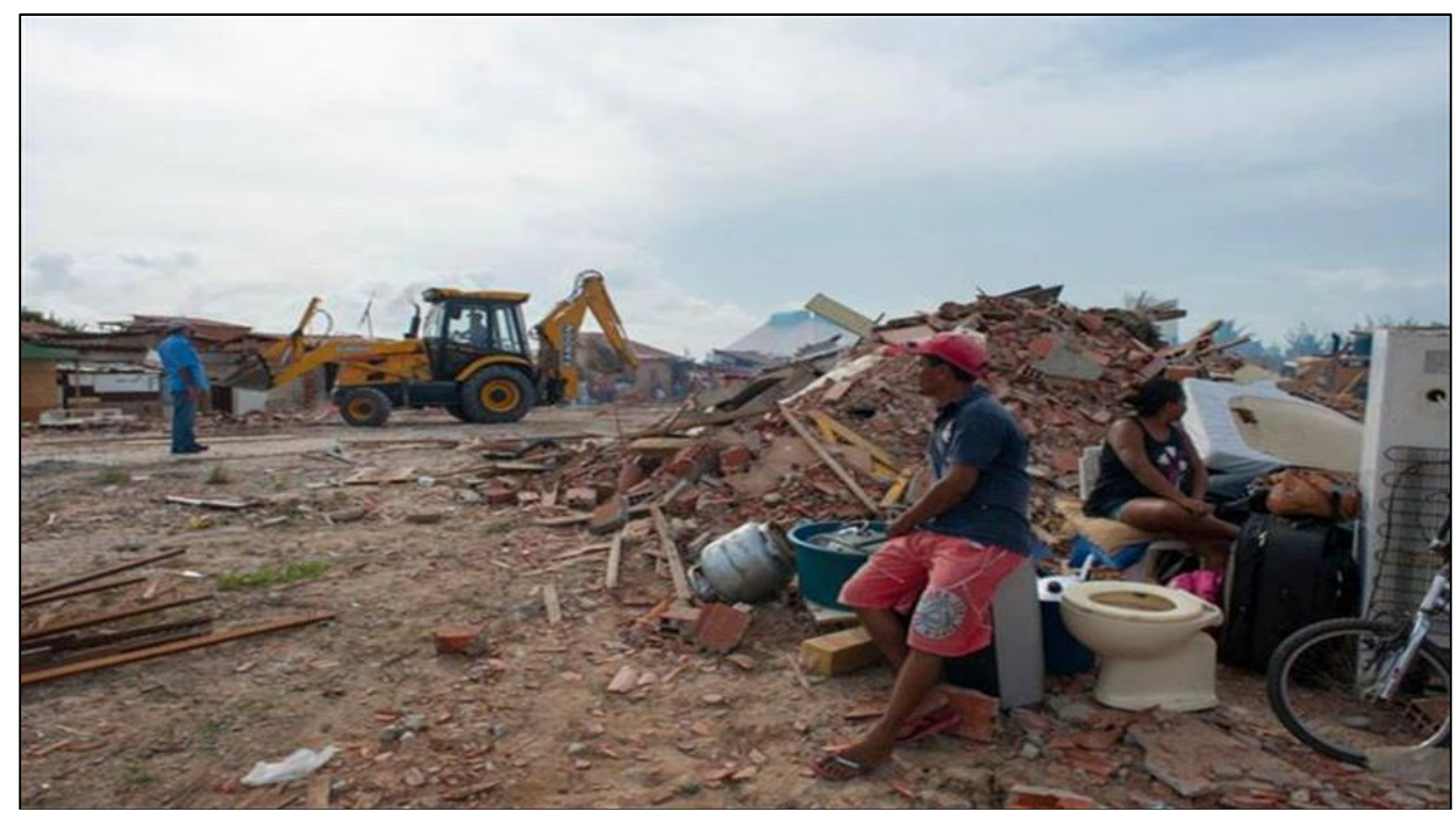

Figura 7 - entulho e objetos pessoais espalhados pelo terreno após desocupação da comunidade do Alto da Paz. Fonte: CNEWS, 2014. 
É em meio à presença de agentes produtores do espaço urbano que a cidade de Fortaleza busca consolidar a atividade turística como base econômica local, alocando políticas públicas de desenvolvimento, modernização da infraestrutura local, promoção de eventos e valorização dos espaços artificializados em função da imagem de cidade com vocação turística, vocação esta pautada na segregação e nos constantes conflitos e resistências das classes menos abastadas.

\section{CONSIDERAÇÕES FINAIS}

O planejamento estatal, buscando a reestruturação produtiva do litoral fortalezense como espaço de elevada importância no mercado turístico nacional e internacional, pauta políticas públicas e equipamentos que estão desconectados das necessidades dos moradores da capital, sobretudo os mais pobres.

O processo de requalificação litorânea perpassa a busca pela inserção das metrópoles no mercado turístico mundial, inserida no período das políticas neoliberais, visando transformar as cidades em commodities (RIBEIRO; SANTOS JUNIOR, 2015). Tal fato não é novo, tendo como casos mais notáveis as ações realizadas pelo Barão de Haussman, em Paris, e por Robert Moses, em Nova Iorque (BERMAN, 2007). O fato novo é a utilização dos megaeventos esportivos como chamariz para atração de pessoas, capitais, informações e técnicas para o território.

Constata-se que a urbanização do litoral Fortalezense atende à demanda das classes mais abastadas, pelo efeito da moda do morar na praia. Pautados nesta visão mercantilista, os especuladores imobiliários elaboram estratégias para apropriação dos terrenos de marinha, dos campos de dunas e das zonas de berma, estas, geralmente, ocupadas pelas comunidades em situação de vulnerabilidade social. Tais ocupações são frutos do deficit habitacional causado pelo rápido crescimento populacional de Fortaleza.

Tal modelo turístico que os planejadores buscam consolidar em Fortaleza segue os moldes de reestruturação dos espaços litorâneos em países como México. Fato comum a estes dois paísesé a de que o turismo suscita certeza de superação da condição de subdesenvolvimento, o que não tornou-se verdade naquele país da América Central (LÓPEZ, 2001) e nem em terras brasileiras. O que se constata são problemas de ordem social como aumento da violência, incidência de casos de prostituição e uma visão positivista sobre o combate à pobreza, a qual é ressignificada no combate aos pobres, ao relacionar o slogan de Cidade da Alegria somente ao litoral turístico da cidade.

Verifica-se que nas duas ultimas décadas os movimentos populares de resistência tem se fortalecido e ganhado apoio de parte da população, sobretudo aquela relacionada aos movimentos em defesa da moradia e dos direitos urbanos. Cabe destacar que há poucas interrelações entre os movimentos destas comunidades aqui citadas, porém o processo de produção do espaço urbano 
tende a favorecer a efervescência destes movimentos, aos quais ainda podem ser incluídas as comunidades do Pirambu, da Barra do Ceará e do Caça e Pesca, configurando assim um litoral heterogêneo e conflituoso, que se pretende turístico pela negação de sua formação histórica.

\section{REFERÊNCIAS}

ALDIGUERI, C. et al. Diagnóstico: Comunidade do Titanzinho. Fortaleza: Unifor CCT, 2015. 33 p. Disponível em: 〈http://issuu.com/karolinnecarvalho/docs/diagn_stico_-_completo>. Acesso em: 12 mai. 2015.

Aquário - Poço da Draga com medo do empreendimento. O ESTADO. 2010. Disponível em: $<$ http://www.oestadoce.com.br/noticia/acquario-poco-da-draga-com-medo-doempreendimento $>$. Acesso em: 06 mai. 2015.

ARAGÃO, R. F. Racionalidade turística e ressignificação do espaço cearense. In: SILVA, José Borzacchiello da.et al.. Litoral e sertão: natureza e sociedade no nordeste brasileiro. Fortaleza: Expressão Gráfica, 2006.

BARROS, F. Na Rota do Turismo Gay. Impressão Digital. 126. 2015. Disponível em: <http://impressaodigital126.com.br/?p=17830>. Acesso em: 05 mai. 2015.

Batalhão de Choque expulsa moradores da comunidade Alto da Paz. O POVO. 2014. Disponível em: $<$ http://www.opovo.com.br/app/fortaleza/2014/02/20/noticiafortaleza,3209611/choque-expulsamoradores-da-comunidade-alto-da-paz.shtml>. Acesso em: 08 mai. 2015.

Beira Mar resgatada. O POVO. 2006. Disponível em: <http://www.opovo.com.br/app/opovo/opiniao/2006/07/06/noticiasjornalopiniao,610136/beiramar-resgatada.shtml>. Acesso em: 08 mai. 2015.

BERMAN, M. Tudo que e sólido se desmancha no ar: a aventura da modernidade. São Paulo: Companhia das Letras, 2007.

BNB. Programa de desenvolvimento do turismo no nordeste. Brasília: Memorando, 2005.

BRAGA, G. H. Turismo brasileiro comemora números do Carnaval. 2015. Disponível em: <http://www.turismo.gov.br/turismo/noticias/todas_noticias/20150223_2.html >. Acesso em: 05 maio 2015.

COMUNIDADE e Prefeitura debateram projeto de habitação. PREFEITURA DE FORTALEZA. 2011. Disponível em: $<$ http://portalantigo.fortaleza.ce.gov.br/habitafor/index.php?option=com_content\&task=view\&i d=12184>. Acesso em: 06 mai. 2015.

CORIOLANO, L. N. M. T. O turismo nos discursos, nas políticas e no combate à pobreza. São Paulo: Annablume, 2006. 
CORREA, R. L. O espaço urbano. São Paulo: Ática, 2004.

CUNHA, G. B.; PEREIRA, A. Q. Os impactos das obras da copa de 2014 no porto do Mucuripe (Fortaleza- Ceará): a implantação do terminal marítimo de passageiros. In: CONGRESSO BRASILEIRO DE GEÓGRAFOS, 7., 2014, Fortaleza. Anais... Vitória: Vii Cbg, 2014. p. 01 - 12. Disponível em: <http://www.cbg2014.agb.org.br/resources/anais/1/1404324086_ARQUIVO_ ArtigoCompleto1rtf.pdf>. Acesso em: 12 maio 2015.

DANTAS, E. W. C. Maritimidade nos trópicos: por uma Geografia do litoral. Fortaleza: UFC Edições, 2009.

DANTAS, E. W. C. Mar à vista: um estudo da maritimidade em Fortaleza. Fortaleza: UFC Edições, 2011.

DEBORD, G. A sociedade do espetáculo: comentários sobre a sociedade do espetáculo. Rio de Janeiro: Contraponto, 1997.

DIAS, L. Redes: Emergência e organização. Em: CASTRO, I. E. de (org.) et al. Geografia: Conceitos e Temas. Rio de Janeiro: Bertand Brasil, 1995. p. 141-162.

ESCOBAR, A. Planning. In. WOLFGANG, S. (Org.). The development dictionary: a guide to knowledge as Power. London: Zed Books, 2010.

ESTUDANTES e militares desfilam na Av. Beira Mar. O ESTADO. 2014. Disponível em: <http://www.oestadoce.com.br/noticia/estudantes-e-militares-desfilam-na-av-beira-mar $>$.Acesso em: 02 mai. 2015.

EVENTOS esportivos impulsionaram turismo em Fortaleza no ano passado. PREFEITURA DE FORTALEZA. 2015. Disponível em: <http://www.fortaleza.ce.gov.br/noticias/setfor/eventosesportivos-impulsionaram-turismo-em-fortaleza-no-ano-passado>. Acesso em: 03 mai. 2015.

GIDDENS, A. Sociologia. Tradução Sandra Regina Netz.4.ed. editora. Porto Alegre: Artmed, 2005.

GOMES JÚNIOR, F. C. Relatório de Impacto Ambiental: Terminal Marítimo de Passageiros do Porto de Fortaleza - CE. Florianópolis: Caruso Jr, 2011. 111 p. Disponível em: <http://www. more.ufsc.br/relatorio_tecnico/inserir_relatorio_tecnico>. Acesso em: 12 maio 2015.

HARVEY, D. A condição pós-moderna: Uma pesquisa sobre as origens da mudança cultural. São Paulo. Edições Loiola, 1993.

HARVEY, D. A produção capitalista do espaço. São Paulo: Annablume, 2005.

LEFEBVRE, H. Espaço e política. Belo Horizonte: Editora UFMG, 2008.

LÓPEZ, A. Anales de la organización territorial del turismo de playa en México de 1970 a 1996: El caso de los Cabos, B.S.S. Tese de Doutorado em Geografia. Universidade Nacional do México, 2001. 
OBRA do mega-aquário do Ceará é paralisada a pedido da construtora. FOLHA DE SÃO PAULO. 2015. Disponível em: $<$ http://www1.folha.uol.com.br/poder/2015/02/1591516-obra-demega-aquario-no-ceara-e-paralisada-a-pedido-de-construtora.shtml>. Acesso em: 05 mai. 2015.

PINHO, A.V.E.; FREITAS, C.F.S. Zonas Especiais de Interesse Social em Fortaleza: Caracterização e Indicação de Vulnerabilidades Através do Sistema de Informação Georreferenciado. In: SIMPÓSIO BRASILEIRO DE CIÊNCIAS GEODÉSICAS E TECNOLOGIAS DA GEOINFORMAÇÃO, 4., 2012, Fortaleza. Anais... Recife: IV SIMGEO, 2012. p. 01 - 07. Disponível em: <https://www. Ufpe.br/cgtg/SIMGEOIV/CD/artigos/SIG/ 103 5.pdf >. Acesso em: 12 maio 2015.

PIMENTA, M. Vitória no Titanzinho: Lula veta construção de estaleiro. 2010. Disponível em: $<$ http://waves.terra.com.br/surf/noticias/variedadesambiente/vitoria-no-titanzinho/lula-vetaconstrucao-de-estaleiro>. Acesso em: 12 maio 2015.

POÇO DA DRAGA: comunidade está prestes a comemorar 107 anos de história. O POVO. 2013. Disponível em:

<http://www.opovo.com.br/app/colunas/opovonosbairros/2013/04/04/noticiasopovonosbairros,3033 206/comunidade-esta-prestes-a-comemorar-107-anos-de-historia.shtml>. Acesso em: 05 mai. 2015.

PRÉ-CARNAVAL de Fortaleza continua com Ilê Aiyê na Praia de Iracema. PREFEITURA DE FORTALEZA. 2015. Disponível em: <http://www.fortaleza.ce.gov.br/noticias/programacaogratuita/pre-carnaval-de-fortaleza-continua-com-ile-aiye-na-praia-de-iracema >. Acesso em: 03 maio 2015.

PREFEITURA LANÇA projeto de urbanização do morro Santa Terezinha. O POVO. 2011. Disponível em: http://www.opovo.com.br/app/fortaleza/2011/05/23/noticiafortaleza,2248107/prefeitura-lancaprojeto-de-urbanizacao-do-morro-santa-terezinha.shtml. Acesso em: 02 maio de 2015.

PRODETUR/NE II - Situação Atual. BNB. Fortaleza, 2010. Disponível em: <http://200.217. 154.7/web/guest/situacao-atual1>. Acesso em: 25 fev. 2015.

PROJETO prevê plebiscito sobre construção de aquário milionário em Fortaleza. UOL. 2013. Disponível em: <http://noticias.uol.com.br/cotidiano/ultimas-noticias/2013/07/15/projeto-preveplebiscito-sobre-a-construcao-de-aquario-milionario-em-fortaleza.htm>. Acesso em: 05 mai. 2015.

QUEM dera ser um peixe. COPA PÚBLICA. 2013. Disponível em: <http://apublica.org/ 2013/06/quem-dera-ser-um-peixe/>. Acesso em: 06 mai. 2015.

RIBEIRO, L. C; SANTOS JUNIOR, O. Governança empreendedorista e megaeventos esportivos: reflexões em torno da experiência brasileira. In: SANTOS JUNOR, O; GAFFNEY, C.; RIBEIRO, L. C. Brasil: os impactos da Copa do Mundo 2014 e das Olimpíadas 2016. Rio de Janeiro: Epapers, 2015.

SECRETÁRIO do Turismo de Fortaleza manda artigo para Blog com balanço das atividades. O POVO. 2012. Disponível em: $<$ http://blog.opovo.com.br/blogdoeliomar/secretario-do-turismo-defortaleza-manda-artigo-para-blog-em-clima-de-balanco-das-atividades/>. Acesso em: 05 mai. 2015. 
SILVA, J. B. da. Quando os incomodados não se retiram: uma análise dos movimentos sociais em Fortaleza. Fortaleza: Multigraf Editora, 1992.

SOUZA, C. Políticas públicas: uma revisão da literatura. Sociologias, Porto Alegre, ano 8, n. 16, jul./dez., 2006. p. 20-45.

UM ANO após despejo de famílias no Alto da Paz, obra não foi iniciada. O POVO. 2015.

Disponível em:

<http://www.opovo.com.br/app/opovo/cotidiano/2015/02/20/noticiasjornalcotidiano, 3395333/umano-apos-despejo-de-familias-no-alto-da-paz-obra-nao-foi-iniciada.shtml>. Acesso em: 08 mai. 2015. 